\title{
Uma Viagem a Parintins
}

\section{Memórias de Pesquisa}

${ }^{*}$ Recebdio em 20.03.2017. Aprovado em: 27.07.2017.

* Doutorando do Programa de PósGraduação em Sociologia da UnB (PPGSOL-UnB), professor de Sociologia da Secretaria de Educação do Distrito Federal (SEDF) e integrante do grupo de pesquisa Cultura, Memória e Desenvolvimento (CMD).

Mestre em Sociologia pelo Programa de Pós-Graduação em Sociologia da UnB (PPGSOL-UnB) e graduada em Artes Cênicas pela mesma instituição, integrante do grupo de pesquisa CMD

Mestre em Sociologia pelo Programa de Pós-Graduação em Sociologia da UnB (PPGSOL-UnB), integrante do grupo de pesquisa CMD Email:

\section{A Trip to Parintins}

\author{
Saulo Nepomuceno ${ }^{* *}$, Juliana Veloso Sá ${ }^{* * *}$ e
} Matheus Lavinscky

Resumo: neste texto, três integrantes do grupo de pesquisa Cultura, Memória e Desenvolvimento relatam, de diferentes perspectivas, a experiência do grupo na etapa de instrução técnica do processo de patrimonialização do Complexo Cultural dos Bois-bumbás do Médio Amazonas e Parintins, levado a cabo pelo Instituto do Patrimônio Histórico e Artístico Nacional (IPHAN). Tem-se por objeto específico do relato a segunda viagem feita pelo grupo àquela região, cujo objetivo foi observar, descrever e dar base empírica às análises acerca do Festival Folclórico de Parintins e seus impactos naquele lugar, além de obter registros audiovisuais, a serem entregues ao IPHAN no formato de um dossiê escrito, um filme de longa e um de curta duração. Partindo do próprio deslocamento feito pela equipe até aquela cidade e observando os impactos do festival sobre ela, buscamos destacar na narrativa alguns dos elementos que justificam o pleito da patrimonialização da manifestação dos bumbás amazônicos, cujo centro, em consonância com a amplitude de suas formas (sociocultural, econômica, de aprendizado intergeracional etc.), é a imersão dos seus símbolos e fazeres nos modos de vida daquela região.

Palavras-chave: Patrimônio Imaterial; Pesquisa de Campo; Festival Folclórico; Parintins.
Abstract: in this text, three members of the Cultura, Memória e Desenvolvimento research group report, from different perspectives, the group's experience in the technical instruction stage of the patrimonialisation process of the Bois-bumbás Cultural Complex of the Medium Amazonas River and Parintins, carried out by Instituto do Patrimônio Histórico e Artístico Nacional (IPHAN). The specific subject of the report is the second travel made by the group to that region, whose goal was to observe, describe and give an empirical basis to the analyzes about the Festival Folclórico de Parintins and its impacts in that place, besides obtaining audiovisual records, to be delivered to IPHAN in the form of a written dossier, a long and a short movie. Based on the team's own displacement to that city and observing the impacts of the festival on it, we sought to highlight in the narrative some of the elements that justify the demand for patrimonialisation of the Amazonian bumbás, whose center, in consonance with the amplitude of its forms (socio-cultural, economic, intergenerational learning etc.), is the immersion of its symbols and actions in the ways of life of that region.

Keywords: Intangible Heritage; Field Research; Folk Festival; Parintins 


\section{Introdução}

O relato seguinte trata da experiência de campo do grupo de pesquisa Cultura, Memória e Desenvolvimento (CMD) no processo de reconhecimento dos bois-bumbás amazônicos (ou, mais precisamente, do Complexo Cultural do Boi-Bumbá do Médio Amazonas e Parintins) como patrimônio imaterial do Brasil, junto ao Instituto do Patrimônio Histórico e Artístico Nacional (IPHAN). A equipe se tornou responsável pela etapa de instrução técnica do processo de patrimonialização após firmamento de Termo de Execução Descentralizada (TED) entre o IPHAN e a Universidade de Brasília, por meio do qual foi atribuída institucionalmente ao Departamento de Sociologia desta universidade - a cargo do CMD e da coordenação de Edson Farias - a responsabilidade sobre o respectivo processo de instrução. O resultado deveria materializar um dossiê e duas peças de audiovisual (de curta e longa duração), além de um corpus fotográfico, a serem analisados pelo conselho consultivo do IPHAN com o objetivo de julgar pela pertinência ou não do reconhecimento daquelas manifestações como parte do conjunto de bens imateriais considerados patrimônios da nação brasileira.

O pleito teve início por parte da Secretaria de Cultura do Estado do Amazonas, a partir de demanda local, fundamentada no reconhecimento prévio do boi-bumbá de Parintins como patrimônio imaterial do estado. Assim, em 2002 foi solicitado o registro a nível nacional, que, ao longo do período transcorrido, das disputas em torno da delimitação do bem imaterial a ser patrimonializado e das reestruturações internas do IPHAN, contou com o trabalho de 2 equipes de pesquisa anteriores, ficando a cargo do CMD a fase de conclusão da investigação técnica do processo de patrimonialização, a partir de 2015 .

Ao total, a pesquisa de campo se consubstanciou em três viagens ao estado do Amazonas, abrangendo as cidades de Manaus, Parintins, Maués e Itacoatiara, além de localidades próximas, distribuídas entre fevereiro e setembro de 2016. Na primeira viagem estiveram presentes o coordenador e um assistente; na segunda viagem, objeto dos relatos deste texto, esteve toda a equipe; e na última viagem apenas o coordenador e três assistentes.

Os preparativos para a segunda viagem ocorreram logo após o retorno à Brasília, com o encerramento da primeira ida a campo. Acertou-se o local onde se hospedaria a equipe do CMD em Parintins e ocorreram reuniões semanais com coordenador e assistentes, nas quais foram trocadas impressões e dados sobre a primeira viagem e comentados textos sobre o folguedo dos bumbás amazônicos.

Além das reuniões de preparação da equipe, nos dias 13 e 27 de maio e 3, 10 e 17 de junho, outras foram feitas juntamente com servidoras do IPHAN. Em 16 de junho ocorreu a segunda reunião com a técnica do IPHAN Amazonas, responsável pela instrução do Complexo dos bumbás amazônicos, e uma das técnicas do Departamento de Patrimônio Imaterial (DPI) do IPHAN nacional. 


\section{Saulo Nepomuceno}

Juliana Veloso Sá

\section{Matheus Lavinscky}

No dia 17 de junho de 2016, às vésperas da viagem, a equipe completa participou de um workshop sobre áudio e audiovisual, coordenado por Rogério Luiz de Oliveira, responsável pelo registro audiovisual da instrução, com o objetivo de se preparar para a feitura das entrevistas na pesquisa do campo. Já em 20 de junho, à tarde, outra vez na sede nacional do IPHAN, a mesma técnica do DPI/IPHAN, durante outro workshop, explanou os critérios básicos que deveriam ser observados em uma pesquisa de instrução para informar a patrimonialização de um bem imaterial.

Foto 01: Workshop do áudio e audiovisual com equipe do CMD (Edson Farias)

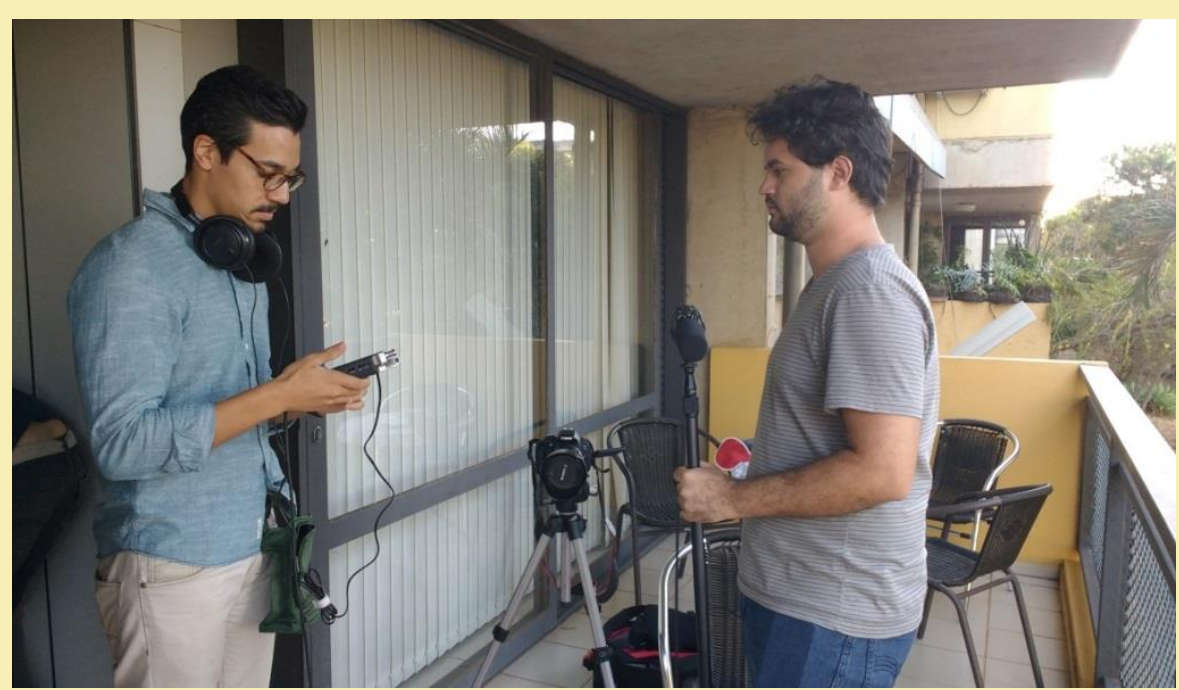

A viagem da equipe do CMD para Manaus, com os sete integrantes, ocorreu no início da tarde de 21 de junho. Já a chegada em Parintins, por via fluvial, aconteceu na madrugada do dia 23. Em meio à atmosfera que se ia instaurando na cidade à medida que o Festival Folclórico se tornava uma realidade, aos poucos a equipe do CMD começou a mapear os focos de interesse no início do trabalho de campo. Nos três dias do evento, dedicou-se a fazer entrevistas com visitantes, moradores, famílias vinculadas ao Garantido e ao Caprichoso e, após os percalços relativos às dificuldades de acessar as dependências do Bumbódromo, compareceu às três noites de apresentações dos bumbás. Passado o Festival, definiu-se uma rotina de trabalho para a equipe, iniciada por volta das 09 da manhã e encerrada por volta das 19 horas, com intervalo de duas horas para o almoço. No alongado de 09 dias, no somatório, o resultado da estada em Parintins se consubstanciou em 35 entrevistas e 53 pessoas entrevistadas, incluindo representantes da ampla e complexa cadeia de produção do festival-espetáculo levado às noites no Bumbódromo. Mas também lideranças e diretores de uma e outra entidade de bumbá, torcedores novos e mais antigos, integrantes das associações, entre outros.

No processo da pesquisa de campo, os integrantes do CMD se ocuparam, cada um, simultaneamente, 1) de uma função de pesquisa referente ao levantamento que daria material ao dossiê e 2) de uma posição (ou posições) operacionais voltadas ao manejo prático da produção audiovisual e dos protocolos do IPHAN. Desse modo, dentre os autores deste texto, Saulo Nepomuceno se dedicou a auxiliar o coordenador, Edson Farias, durante a condução das entrevistas, fazendo questionamentos aos entrevistados e 


\section{Saulo Nepomuceno}

Juliana Veloso Sá

registrando-as, além de contribuir com observações de caráter mais etnográfico sobre a cidade de Parintins e a dinâmica do Festival Folclórico. Juliana Veloso Sá se ocupou, do ponto de vista operacional, do trabalho de auxiliar de produção do audiovisual e de registro documental do IPHAN, além de contribuir para o registro escrito da instrução técnica com observações descritivas e interpretativas acerca dos aspectos cênicos, de vestuário e performance do espetáculo dos bumbás. Matheus Lavinscky, por sua vez, tratou de tecer observações a respeito da cidade no contexto do festival, além de registrar o processo de deslocamento que levou a equipe do CMD a Parintins e seus percalços, e auxiliar como operador de áudio na gravação das entrevistas e apresentações musicais e cênicas.

A seguir, dividido em três itens, é apresentado um panorama da viagem do ponto de vista dos três integrantes da equipe que assinam o texto.

\section{a) Percorrendo o Rio}

\section{Por Matheus Lavinscky}

A incursão teve início com uma aparente dificuldade operacional que se mostrou frutífera no que se refere às estratégias de entrada no campo. Para o translado Manaus - Parintins, havia sido feita com antecedência uma reserva de poltronas para a equipe numa lancha, transporte rápido que possibilita a viagem entre as duas cidades pelos rios Negro e Amazonas em cerca de oito horas, o que, a princípio, nos seria importante por fazer o percurso no menor tempo possível. Esperávamos chegar a Parintins o quanto antes e, assim, acompanhar as expectativas suscitadas pela iminência da festa e a mobilização da cidade em torno da feitura do Festival Folclórico de Parintins.

Foto 02: Porto de Manaus (Edson Farias)

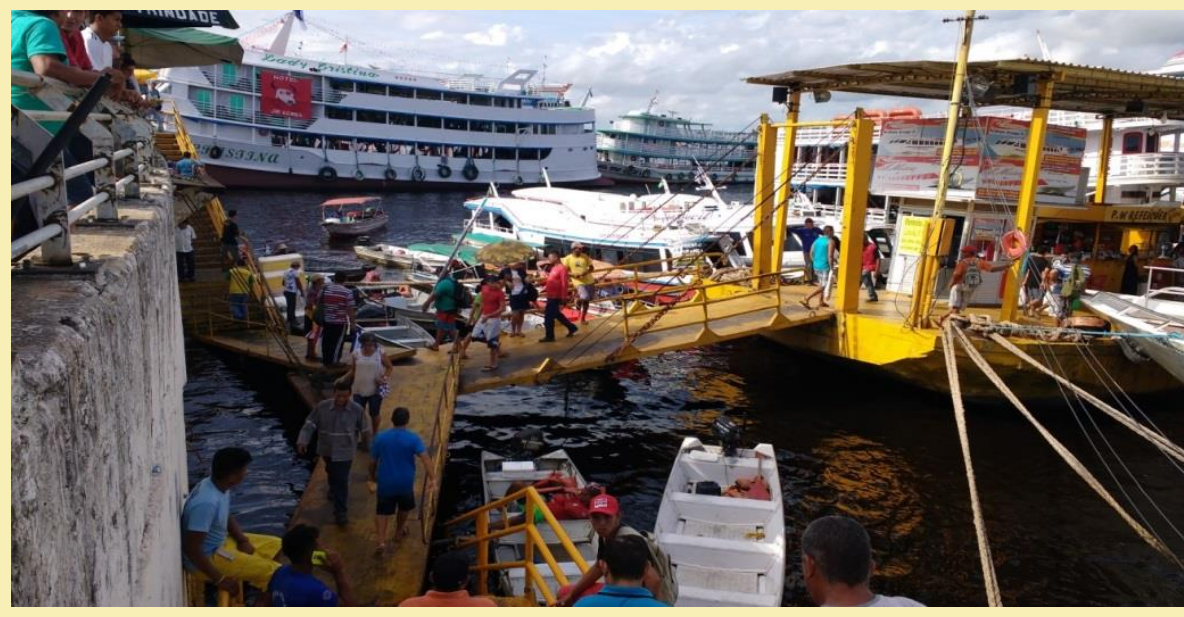

A reserva que imaginávamos pronta, cuja solicitação havia sido registrada e confirmada nas mensagens de e-mail do coordenador da equipe, na verdade, não se sabe bem por qual ordem de dificuldades, não havia se efetivado na empresa responsável pelo transporte. Antes das seis da manhã estávamos já no porto de Manaus, preparados para a viagem, quando descobrimos que não tínhamos reserva e, assim, nosso embarque não seria possível naquele transporte e naquele horário. Esta parecia uma primeira dificuldade de campo, porque atrasaria a nossa chegada ao destino e nos imporia um acréscimo de tempo ocioso imprevisto. 
De fato, de uma partida prevista para 06 horas do dia 22 de junho de 2016, após algumas horas de espera e irresolução no porto de Manaus, passamos à possibilidade de embarque às 10 horas, em uma embarcação de tipo diferente. Da lancha inicial, que sairia às 06h e faria a viagem em cerca de oito horas, passamos para um barco, com maior capacidade de lotação e para o qual seria possível obter bilhetes naquelas circunstâncias, às pressas, que sairia às $10 \mathrm{~h} e$ chegaria ao destino apenas no dia seguinte, pela manhã. Tal contingência nos pareceu, no momento, uma dificuldade incontornável e certo ônus a ser suportado.

O porto estava movimentado, um fluxo intenso de pessoas, bagagens e mercadorias preenchia os espaços nas escadarias, na plataforma flutuante de embarque e desembarque, entre o Rio Negro, as embarcações aportadas e as barracas comerciais da plataforma, nas quais se vendia uma variedade de comida (pratos feitos com diferentes tipos de carne assada e frutas, principalmente), bebida, utensílios domésticos e objetos para a viagem. Aí já se anunciava a expectativa para o festival de Parintins. Barcos decorados com fitas e bandeirolas em azul, vermelho e branco, imagens de bois pretos e brancos, corações e estrelas, ao tempo que faziam parte de uma prestação de serviço de transporte, remetiam aos símbolos de Parintins e, assim, definiam já uma ambiência adequada àqueles que buscavam bilhetes e lugares para a viagem à ilha Tupinambarana.
Foto 03: Porto de Manaus (Edson Farias).

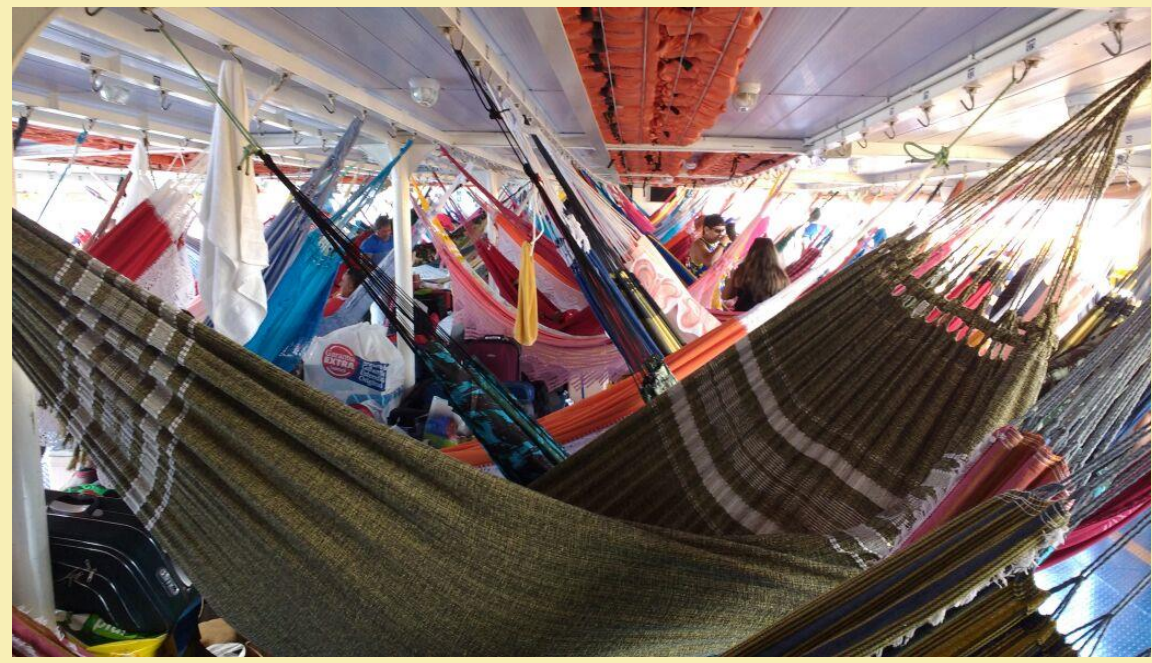

À despeito de a partida do barco, anunciada para as 10 horas, ter se dado, de fato, por volta das $11 \mathrm{~h} 30$, toda a viagem permitiu uma entrada em campo inesperadamente produtiva. A permanência mais prolongada que o previsto no porto de Manaus possibilitou, além da captação de rico material audiovisual em meio à paisagem portuária amazônica - e em consonância com esta -, apreender a ambiência que se configurava para o festival. Isso se mostrava nas campanhas e formas de abordagem postas em prática pelos prestadores de serviços de transporte fluvial; no modo como estava disposta uma rede de serviços voltada à demanda suscitada pelo festival; na decoração das embarcações; além de, claro, nas conversações entre os viajantes e na própria objetivação da escolha do destino para a viagem. 


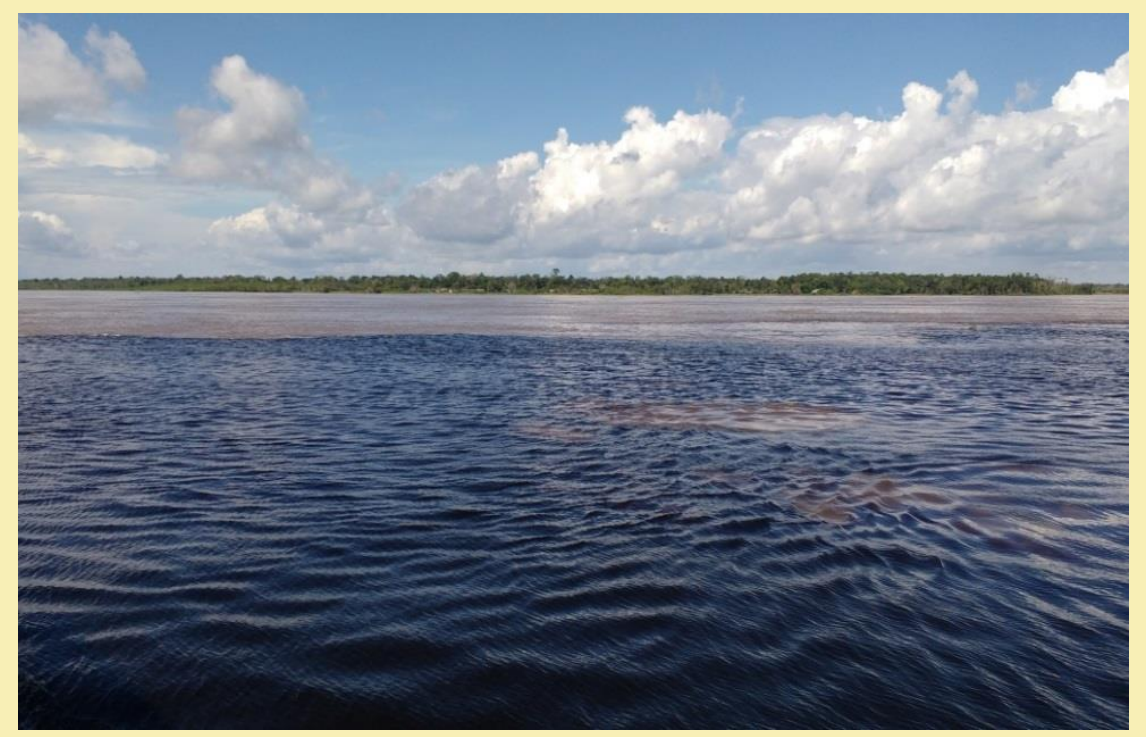

Foto 04: Barco de passeio (Edson Farias).

O mesmo se deu na extensão do percurso. A permanência prolongada no trânsito entre as cidades (até por volta das 04 horas, do dia 23 de junho de 2016) abriu possibilidades valiosas de observação e registro audiovisual junto aos viajantes, em meio à densidade da floresta, das águas e paisagem amazônicas, naquela ocasião atravessadas pelo barco de três andares - dois dos quais ocupados por redes, malas, sanitários e refeitório, e em cujo topo se encontrava uma área de convivência na qual se fazia uma festa constante: onde se bebia, comia e escutava uma variedade de músicas de diversas regiões do país (além das típicas toadas que acompanham as apresentações dos bumbás, que já despertavam os presentes para o que viria nos dias próximos).

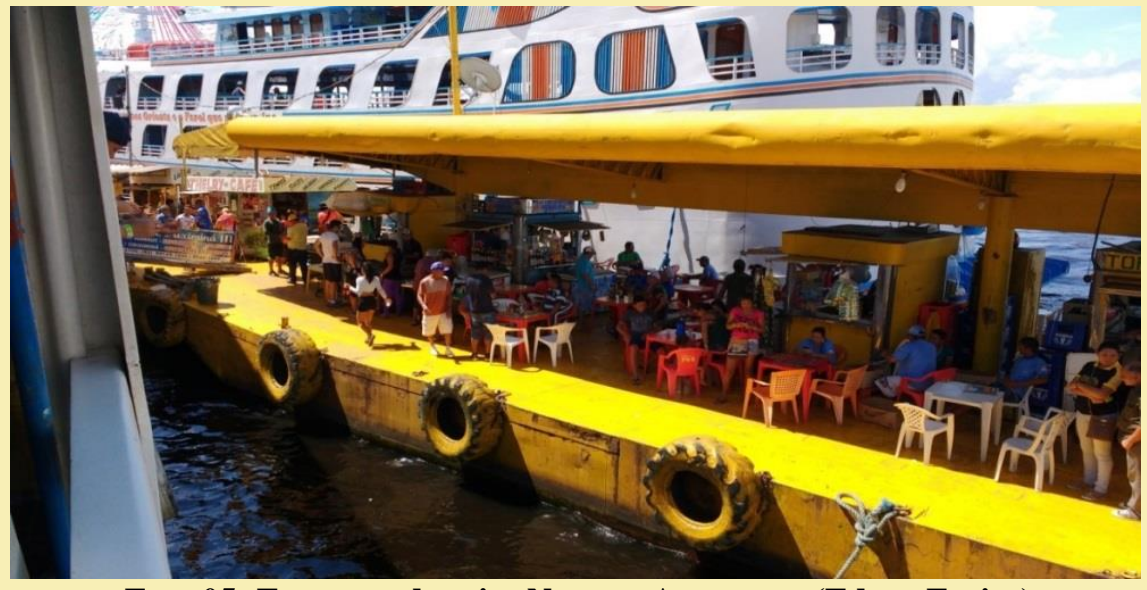

Foto 05: Encontro dos rios Negro e Amazonas (Edson Farias)

As necessidades de consumo dos passageiros para aquele tipo de ocasião eram bem satisfeitas pelo aparato de serviços do próprio barco: no andar mais alto do barco, onde se fazia a festa, havia uma oferta constante de alimentos (principalmente sanduíches preparados na hora e lanches industrializados) e cervejas. Neste andar se proporcionava a satisfação dessas necessidades de consumo, com a adição de uma estrutura adequada à execução de música ao vivo (em voz e violão). Era onde acontecia a festa, e a preparação para o festival assumia um tom de prévia, ao menos no que se refere ao tipo de disposição necessária. Configurava-se no translado uma espécie de festa transamazônica fluvial em direção a Parintins.

Dos viajantes, grande parte seria participante do festival em clima de preparação para os dias de festa (outra parte seguiria no barco até a cidade de Oriximiná, no Pará). As falas dos 
participantes, se já eram de importância fundamental para os propósitos do nosso levantamento por expressarem as atribuições de sentido que animam a participação no festival e a relevância do folguedo do boi em suas vidas, foram valorizadas pelo próprio contexto em que foram captadas, sob condições partilhadas também pela equipe de pesquisa.

O compartilhamento dos espaços de vivência, alimentação, repouso e diversão no barco, decorrente do que a princípio pareceu uma dificuldade, ensejou circunstâncias de aproximação com os viajantes - dos quais boa parte dali a pouco se tornaria "galera" no festival - cuja importância no processo de levantamento não pode ser minimizada. Foi a base para a identificação de interlocutores potencialmente importantes para o registro, o que se materializou nas cinco entrevistas realizadas nessas circunstâncias, das quais participaram oito pessoas, cujos relatos retratam, de modo geral, as maneiras de ingresso na torcida dos bois Garantido e Caprichoso ou outra atividade mais específica desenvolvida junto às equipes dos bois, além dos significados assumidos por tal participação em suas trajetórias pessoais.

Aí já se pronunciavam elementos que seriam recorrentes no conjunto das entrevistas durante toda a incursão: a relevância da influência familiar, da transmissão intergeracional na origem do tão referido sentimento que nutre a mobilização e empenho das pessoas na brincadeira do boi e no festival de Parintins. Aquilo que constantemente era referido como sentimento ou emoção transparecia na própria emotividade acentuada com que as pessoas reagiam quando convidadas a dar entrevista sobre o tema. Em geral, os interlocutores pareciam muito satisfeitos ao falar do boi, de sua torcida ou da festa, como um todo.

Também começavam a se anunciar as percepções acerca da particularidade da realização do festival no ano de 2016: a tão falada crise e a apreensão relativa aos impactos do corte de repasse - principalmente do governo estadual - sobre o festival, o que, segundo algumas entrevistas no decorrer e posteriormente ao festival, teria se concretizado na redução da grandeza do espetáculo. Mas, ao mesmo tempo, como destaca Ericky Nakanome, coordenador de figurino e integrante do conselho de arte do Caprichoso, a mesma crise suscitou um engajamento mais espontâneo e direto da população na produção da festa, com doação de alimentos e trabalho para as equipes dos bois (no caso em que poderia falar com maior propriedade, do Caprichoso). Isto configurou uma espécie de "retorno", resultante da intempérie, ao antigo molde do festival, menos especializado e organizado de modo empresarial, e mais ancorado no trabalho dos apoiadores, como costumava ser antes do estabelecimento do formato de espetáculo, segundo o entrevistado.

As consequências dessa circunstância foram além da modulação na gestão do trabalho interno à produção do festival. Em conversas mais informais com os viajantes/ brincantes (aqui em especial Cleyton, torcedor e mobilizador do Caprichoso em redes sociais), ainda no barco, se relatou que, devido a este fato, foram organizadas manifestações no centro de Manaus, responsáveis por 
reunir partícipes dos dois bois, a fim de pressionar o governo estadual por participação econômica na realização do festival de 2016. O que sustentava a demanda e a pressão políticas da ocasião parecia ter a ver com um entendimento da importância daquela forma de expressão para a identidade local.

Alterações políticas incidentes sobre o festival e o tipo de apreensão que provocam, como as desse ano, parecem pôr em relevo um ponto de sensibilidade sociocultural relativo à importância atribuída pelos participantes àquele festejo, entendido como expressão forte da sua particularidade local, amazônica $e$ cabocla, cujo sentido de pertencimento por meio da brincadeira e também do espetáculo do boi em Parintins é objeto de aprendizado e transmissão familiar. Nesse quesito, também foi visto com rejeição (pelos entrevistados que tocaram no tema) um decreto, neste ano, que proíbe a presença de crianças nas galeras, sob a percepção de um prejuízo em relação à transmissão do saber e aprendizado da festa provocado por esta medida.

Conforme se depreende das falas, o espetáculo do Festival Folclórico de Parintins é parte, o ponto alto (para muitos dos entrevistados), de um continuum que abrange atividades, projeção de expectativas e outras manifestações culturais correlatas, dispostas numa variação tanto de espaço quanto de tempo, visto que não se restringe a Parintins e aos três dias de festival. Mesmo sem considerar diretamente o tempo de produção do festival, vimos que, ao longo do ano, de um lado, são organizados eventos para arrecadação de recursos e preparo das torcidas por apoiadores dos dois bois, principalmente em Manaus e em Parintins (como o "bar do boi”, as feijoadas, ensaios abertos dos grupos percussivos Marujada de Guerra no Caprichoso e Batucada no Garantido - e mesmo brincadeiras de boi de rua); de outro, pessoas de diferentes localidades, os torcedores, tanto no entorno mais próximo a Parintins (registre-se a particularidade das distâncias amazônicas) quanto em diferentes regiões mais distantes do país (nesse caso, principalmente, pessoas daquela região que migraram ou ainda outros, que conheceram o espetáculo pela televisão), se organizam durante todo o ano, individualmente ou - principalmente - em grupos de amigos e familiares, para que seja possível estar lá nesse período, estimuladas por uma possibilidade de satisfação de estimas de acentuado caráter regional. Como afirma a entrevistada Lena, torcedora do Garantido, para isso é necessário "dar um jeito" de estar lá. Encerrado um ciclo, com o fim do festival, é hora de começar a preparar a próxima viagem a Parintins e "dar os jeitos" necessários para a sua viabilidade.

Esse referido ponto de sensibilidade não está dissociado da percepção da importância do festival para a economia local. Isso se mostra na própria afirmação de Cleyton. Segundo esse entrevistado, haveria, por parte do governo atual, uma dificuldade em perceber o festival como um investimento, como um estímulo à economia loca atrelada à circulação de pessoas impulsionada pelo festival, o que é indissociável da visibilidade conferida aos símbolos locais, cujos efeitos se estendem por todo o ano. 
1 Local onde são realizadas as apresentações dos Bumbás de Parintin durante o Festival Folclórico. Será apresentado na seção 2. Lugares.
Foi recorrente (e emblemática) a informação de que o governo estadual estaria financiando espetáculos de ópera em detrimento do Festival de Parintins, o que parece uma maneira de reiterar a restrição do sentido de cultura ao de alta cultura, o verdadeiramente cultural como o erudito, em detrimento de uma manifestação que retrata a história, os saberes, os símbolos, a atribuição de valor e sentido arraigados no local.

O impacto econômico é amplamente observável ao se chegar à cidade já no período que precede em pouco o festival - dia 23 de junho, no nosso caso. Se torna possível percebê-lo mais ainda ao permanecermos após os dias de festa: passado o ápice dos dias de festival, é facilmente observável a diminuição do fluxo de pessoas na cidade, a desaceleração do seu ritmo e a contração da esfera dos negócios possíveis ali.

\section{b) As noites no Bumbódromo}

\section{Por Juliana Veloso Sá}

\section{Formas de expressão}

A apresentação dos Bois Bumbás Caprichoso e Garantido, em Parintins, aconteceu nos dias 24, 25 e 26 de junho de 2016. Ao longo dessas três noites, cada Boi ocupou a arena do Bumbódromo ${ }^{1}$ por duas horas e trinta minutos, num total de cinco horas, além do breve intervalo entre uma apresentação e outra.

As apresentações têm caráter competitivo. Um corpo de jurados é convidado a cada edição do Festival Folclórico para avaliar 21 itens estruturantes da performance e, dessa forma, eleger o campeão do ano. Atualmente, os itens julgados são:

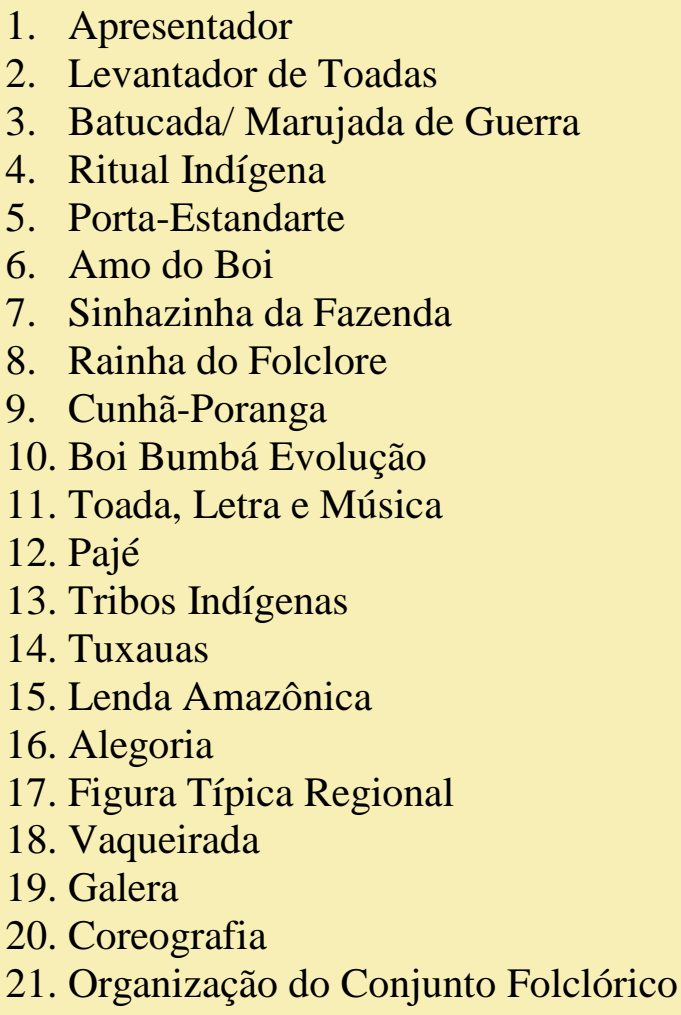

\section{Dramaturgia e Apresentação}

Anualmente, cada Bumbá escolhe um tema a ser desenvolvido nas três noites de apresentação, sendo que cada uma 
${ }^{2}$ Alguns dos entrevistados se referiam às apresentações como "espetáculo", sem que isso implicasse a perda de seu caráter folclórico. Eles veem isso como uma adaptação própria do Bumbá de Parintins, a articulação entre folclore e arte.

\section{Matheus Lavinscky}

delas terá um subtema específico. O tema é trabalhado sob a forma de um roteiro para os espetáculos e orienta todo o processo de criação, desde as toadas até as coreografias, figurinos, alegorias etc.

Em 2016, o tema do Garantido foi "Celebração", com o mote de celebrar a diversidade cultural brasileira e a arte e cultura de Parintins. A primeira noite versou sobre "Ancestralidade", a segunda, sobre "Tradição e Fé", e a terceira, sobre "Folclore Amazônico". Já o Boi Caprichoso elegeu o tema "Viva Parintins!", uma homenagem aos parintinenses e sua cultura, seus costumes e tradição. Na primeira noite, exclamou na arena um "Viva Nosso Folclore!", na segunda noite, "Viva Nossa Floresta!".

As apresentações se estruturam em cenas ("quadros artísticos") compostas por alegorias, alguns personagens centrais e grupos de dançarinos que executam coreografias específicas, um grupo de milhares de pessoas que cantam e torcem (a Galera), tudo em sincronia com a música tocada ao vivo pela Batucada ou Marujada de Guerra. Cada um desses aspectos será melhor apresentado ao longo do texto.

Em termos dramatúrgicos, no Bumbá parintinense o auto do Boi se mistura com outras tantas narrativas, em sua maioria referentes à Amazônia e à natureza - sendo que estes últimos tomam formas variadas a cada ano. A temática indígena é central nas apresentações: é citada nas toadas, que se referem a etnias específicas e usam termos indígenas; toma a forma de alegorias diversas e aparece nas figuras do Pajé, dos Tuxauas e das tribos.
Nessa edição do Festival, em uma das noites o Garantido encenou a morte e ressurreição do Boi. Esse "quadro artístico" ocupou pouco tempo das duas horas e trinta minutos de apresentação. Foi encenado pelos personagens típicos do auto Mãe Catirina, Pai Francisco, Cazumbá, Amo do Boi, Boi e seu Tripa -, ao som de uma música instrumental, e seguido por uma toada em tom mais dramático. Não havia alegorias para essa cena, que se desenrolou numa parte pequena da arena, onde se concentravam esses personagens, em frente à Batucada. No centro da arena, grupos dançavam uma coreografia que se repetia de modo ritmado. Isso apenas para ilustrar o pequeno acento que recebeu o auto na apresentação dos Bumbás de Parintins, na edição de 2016. Completamente distinto da grandiosidade das cenas sobre figuras típicas da Amazônia, suas lendas e rituais indígenas.

Cada alegoria, cada conjunto de personagens e cada cena se seguem uns aos outros, sem que haja uma relação causal entre eles ou uma interação de outro tipo. A dramaturgia das apresentações se constrói de forma fragmentada, a partir de uma sequência de cenas independentes, que possuem uma estrutura própria, com início, meio e fim. Algumas toadas ou trechos delas se repetem no decorrer da apresentação, como a toada voltada para a Galera, o que ajuda a criar uma coesão no espetáculo ${ }^{2}$. A repetição de algumas músicas se deu não só em um mesmo dia de apresentação, como nos três. O Apresentador e o Amo do Boi, figuras que ficam do início ao fim do espetáculo, também contribuem para essa coesão. 
Cada noite de espetáculo se estrutura em torno de "quadros artísticos" independentes, cenas com narrativas específicas, que se dão a conhecer por meio da introdução feita pelo Apresentador e pelas toadas e alegorias elaboradas especificamente sobre cada lenda, mito ou ritual apresentado. Os quadros têm propostas específicas e narram cada um uma história, que converge com o tema do Festival e com a temática da noite. Os itens individuais integram essas cenas. Alguns transitam por diferentes quadros, outros estão atrelados a um específico, como é o caso do Pajé, que protagoniza o Ritual Indígena. Os quadros se iniciam com a entrada de brincantes ou de alegorias; em seu desenvolvimento, as alegorias se organizam na arena, alguns itens surgem, enquanto corpos de dançarinos distribuídos pelo espaço desenvolvem sequências coreográficas; e termina com a retirada das estruturas alegóricas e dos dançarinos, com o esvaziamento da arena.

Os quadros artísticos são: Ritual Indígena, Lenda Amazônica, Figura Típica Regional e Celebração Folclórica. A cada noite são apresentadas diferentes histórias por quadro artístico. O primeiro celebra a figura do Pajé e sua força como guia espiritual. Costuma apresentar um transe do Pajé, seu trânsito entre os mundos real e sobrenatural, e o enfrentamento de maléficos espíritos para devolver o bem à aldeia e reestabelecer a harmonia. É o momento mais apoteótico e dramático do espetáculo. Este ano, o Caprichoso apresentou o Ritual Kagwahiva, Manhoagaripi e o Rito Ju'riju'rihuve'e. O Garantido, por sua vez, levou à arena o Ritual Karajá, Kanamari e Yurupari.
De caráter fantástico, a Lenda Amazônica remonta a seres encantados da floresta e da região. O Garantido encenou as lendas do Monstro Yapuritã, dos Macacos Vermelhos e das Amazonas. O Caprichoso contou a lenda do Juma e da fera dos rios - Tandavú.

Figura Típica Regional é o nome do quadro dedicado a tipos próprios da região amazônica, surgidos das diversas "misturas" socioculturais que ali se processaram, envolvendo negros, índios e brancos. Alguns deles são os romeiros de festas religiosas, os caboclos, seringueiros, juteiros, pescadores, etc. Este ano, o Caprichoso homenageou as Benzedeiras, com destaque para o curandeiro parintinense Seu Valdir Viana, em uma das noites, e o Pescador, em outra. O Garantido, por sua vez, levou à arena o Caboclo Sacaca, os Romeiros da Fé e o Seringueiro.

Por fim, o quadro Celebração Folclórica, próprio do Garantido. Ele costuma abordar o tradicional auto do boi. No terceiro dia de festa, celebrou a Amazônia e a transformação do Bumba-meu-boi em Boi Bumbá. Na segunda, celebrou a Tradição e Fé próprias da identidade da Baixa do São José, vila onde nasceu o Garantido. Na primeira, a Diversidade Cultural foi o tema celebrado. Desta vez, sem referências diretas ao Boi, abordou elementos que compuseram a formação do povo brasileiro, seus folguedos e religiosidade. Esse quadro demonstrou estreita relação com o subtema de cada noite de apresentação do Garantido.

Com relação à interação entre os itens individuais ou personagens, observou-se que também não havia tensões ou interação significativa entre eles. Vez ou outra a Sinhazinha fez 
carinho no Boi ou aconteceu alguma interação entre personagens em cena, sobretudo envolvendo o Boi e entre Pai Francisco, Mãe Catirina e Cazumbá, mas não houve conflitos. Pareciam personagens saídos de uma história, que chegavam e se apresentavam, cada um com suas características e sua biografia, mas sem interagirem de modo a dar encaminhamento a uma narrativa, sem que um conjunto de ações convergisse ou colidisse e gerasse resultados determinados.

$* * *$

No início da primeira noite de apresentação, entraram os jurados do Festival Folclórico. Em um telão foi exibido um vídeo sobre o Festival, falando da crise política que o país enfrentou no último ano e das dificuldades para a realização da $51^{\mathrm{a}}$ edição. As pessoas que compunham a Galera do Garantido e do Caprichoso se manifestaram com gritos entusiasmados durante o vídeo. $\mathrm{Na}$ exibição também eram apresentados os patrocinadores do Festival. Ao longo da apresentação, este telão exibiu detalhes das cenas captadas simultaneamente pela TV A Crítica.

Em seguida, foi a vez do Apresentador, seguido pelo Levantador de Toadas, compositores e músicos entrarem. A música se inicia antes mesmo que os músicos estejam devidamente posicionados. O Levantador de Toadas começou a cantar e se remeteu à Galera do Garantido, Boi que tomava conta da arena no primeiro momento, aquele dia, e foi acompanhado em coro. A
Batucada do Garantido entrou e se posicionou em dois blocos, deixando um corredor entre eles, em um extremo do Bumbódromo, de frente para a arena. Essa forma de organização se repetiu nas apresentações de ambos os Bumbás. Os demais personagens não entram de acordo com uma ordem fixa, mas se deram a ver aos poucos, ao longo da apresentação.

Antes do surgimento das principais personagens, o Apresentador introduzia quem era e qual o seu número na ordem dos itens avaliados. A transição entre as cenas era também narrada pelos versos do Amo do Boi, enquanto as alegorias e grupos de dançarinos entravam e saíam.

Durante ou entre uma canção e outra, o Amo do Boi narrava lendas e histórias relacionadas à cena. A música demonstrou-se um elemento central e não cessou durante o espetáculo. Quando não eram cantadas toadas, ela continuava, mesmo que somente instrumental, criando uma atmosfera, enquanto algo era narrado. A narração conduzida pelo Apresentador e pelo Amo do Boi, bem como as músicas, davam sequencia à apresentação e introduziam as cenas. Alternavam-se os processos de ocupação e desocupação da arena, com entradas de dançarinos, itens e alegorias, a cada quadro artístico. O conjunto de elementos compunha uma imagem quando tomava a arena como um todo, imagem sempre pulsando em movimento - dos dançarinos ou das alegorias. Em seguida, ela era desocupada, de modo mais rápido do que o processo de sua ocupação. 
Alguns efeitos foram utilizados para dar mais destaque a determinado elemento ou para provocar surpresa naqueles que assistiam. Para citar alguns exemplos, em uma das entradas do Pajé do Garantido, ele disparou um jato de luz, que vinha de um objeto que segurava. Tal efeito ressaltava esse item e seu caráter mágico. Em uma das entradas da Sinhazinha do Garantido, foram jogados papéis picados sobre ela, o que, junto com a iluminação, criava um efeito de brilho sobre esta figura. Um momento de surpresa e excitação foi quando, na cena final do Caprichoso, no terceiro dia, um grupo de pessoas que seguravam um terço feito de balões, soltou-o no ar e ele começou a flutuar, até que se desprendeu e voou para fora do Bumbódromo. A música e a Galera acompanharam com grande excitação esse momento, dotando-o de mais intensidade.

\section{Personagens}

Os personagens centrais dos Bumbás de Parintins, também chamados de itens (individuais), são compostos, principalmente, por figuras típicas do auto do boi e outras relacionadas ao universo indígena. No Festival Folclórico, privilegiam-se pessoas de Parintins para desempenhar esses papéis. Alguns o fazem por muitos anos consecutivos, como o Pajé e o Tripa do Garantido, há 18 e 21 anos, respectivamente.

Cada personagem ou grupo deles desempenhava uma coreografia específica a cada noite, elaboradas por distintos coreógrafos. A coreografia, como a música, praticamente não era interrompida ao longo do espetáculo. Entravam e saíam grupos dançando, fazendo diferentes desenhos no espaço e ocupando-o de distintas formas. Os corpos de dança costumam executar movimentos que se repetiam por longos minutos ou possuíam pequenas variações, sobretudo utilizando-se de gestos com os braços e pequenos deslocamentos pelo espaço (frente e trás, direita e esquerda, diagonais), sem que saíssem efetivamente do lugar, sempre bastante ritmados, em sincronia dos bailarinos entre si e com a música. Os personagens individuais (Pajé, Rainha do Folclore, Cunhã Poranga etc.) executavam coreografias exclusivas para cada um deles num solo ou acompanhados de grupos de dançarinos, que realizavam outra coreografia. A ocupação do espaço pelos itens individuais se dava de forma mais aleatória e menos geométrica que a dos corpos de dançarinos.

Os personagens Pai Francisco, Mãe Catirina e Cazumbá permaneciam em cena grande parte do tempo, entravam e saíam sem serem anunciados. Estão fora do conjunto de itens julgados, mas não foram excluídos das apresentações. Suas performances eram mais cênicas que coreográficas. Apareciam saltando de um lado para o outro, dançando de modo mais solto e espontâneo, brincando um com o outro, em tom cômico. Interagiam, por vezes, com o Boi: este empurrou Mãe Catirina e ela rolou no chão; Pa Francisco o puxou pelo rabo.

Abaixo, uma breve apresentação sobre as principais personagens: 


\section{Saulo Nepomuceno}

Juliana Veloso Sá

\section{Matheus Lavinscky}

\section{- Apresentador}

É o mestre de cerimônia, personagem que conduz o espetáculo, apresenta os itens à medida que aparecem, conta a história do boi e o tema escolhido para o Boi.

- Levantador de Toadas

É aquele que canta todas as toadas, durante as três noites de espetáculo.

\section{- Porta-Estandarte}

Personagem que carrega o estandarte de cada Boi, representando sua associação folclórica. "o bailado desse item, precisa conduzir com dignidade o pavilhão e ao mesmo tempo ser a bandeira de guerra da jovem dançarina que o porta" (Roteiro do Caprichoso, 2016). Já o Garantido ressalta este item como "Símbolo da resistência cultural", que se manifesta no figurino, no biotipo indígena daquela que dança e na sua condição de mulher, referência às guerreiras Amazonas que resistiram à colonização (Roteiro do Garantido, 2016).

- Amo do Boi

Personagem tradicional do auto do boi, é o dono da fazenda e do boi. Sua fala em versos pontua todo o espetáculo e deve desafiar e provocar o Boi contrário.

- Sinhazinha da Fazenda

É a filha do Amo, loira e de cabelos cacheados, usa um vestido comprido e rodado, luvas finas e uma delicada sombrinha ou leque. Com gestos delicados e sinuosos com os braços, a Sinhazinha dança, girando sua saia enorme, fazendo-a saltar ao ritmo da música.

- Rainha do Folclore

Personagem que remete às diversas manifestações folclóricas e folguedos brasileiros. Sua coreografia faz referência a diferentes tipos de dança, como a indígena, a cabocla, a nordestina.

\section{- Cunhã-Poranga}

A índia mais bonita de uma tribo. "Seu bailado une força e sensualidade, movimentos firmes e leves" (Roteiro do Caprichoso)

\section{- Boi Bumbá e o Tripa}

Tripa é aquele que dá vida ao boi de pano com sua dança ao vestir sua carcaça. É também quem confecciona o brinquedo. E o Boi é o personagem símbolo do Festival. A dança do Boi Bumbá é bastante articulada e vigorosa, mexe a cabeça para um lado e para o outro, ou para cima e para baixo, como se desenhasse um "S" no ar, joga sua trazeira para cima, sacode o rabo, gira. O tripa agacha em alguns momentos e utiliza o nível baixo.

- Pajé

É um dos personagens mais performáticos do Boi Bumbá, marcado por um caráter místico. É o curandeiro e líder espiritual da tribo, que protagoniza as cenas de ritual a cada apresentação.

- Tribos Indígenas

Grupo de pessoas que, a cada noite, representavam alguma etnia indígena específica. Compunham coreografias de caráter mais arrojado que os outros grupos de dançarinos, com um acento mais acrobático, envolvendo quedas, saltos e pirâmides humanas, e movimentos sequenciados, como em "efeito dominó". Utilizaram muitas vezes o nível baixo, deitando-se no chão da arena.

"Formado por estudantes inseridos nos programas sociais do boi, compõem um elenco de 240 figurantes que atuam nas três noites do festival". Participam das cenas de rituais ou mitos do universo indígena (Roteiro do Garantido, 2016). Segundo o Roteiro do Caprichoso, o corpo de dança das tribos contam com mais de 160 jovens.

- Tuxauas

São os grandes chefes indígenas. Cada dançarino conduz uma "indumentária em proporções agigantadas" (Roteiro do Caprichoso), verdadeiros "cocares alegóricos", segundo o Roteiro do Garantido. Cada figurino destes, de caráter alegórico, em função de suas proporções, é sustentado por um único homem, e pode chegar a pesar 70 quilos. Eles contêm os principais elementos da 
3 No Roteiro do Caprichoso dão a entender que este não é o termo mais apropriado: "Denominou-se Alegoria este item para facilitar sua compreensão, porque em verdade trata-se de grandiosos cenários". etnia a que se referem. O principal movimento dos Tuxauas é se deslocar pela arena.

\section{- Vaqueirada}

Grupos de vaqueiros, em torno de 40, encarregados de proteger o Boi. No Garantido, fazem parte da Celebração Folclórica. Sua coreografia era marcada principalmente pelo deslocamento pelo espaço, realizando desenhos, como círculos que giravam em sentidos contrários ou um grande círculo envolvendo toda a arena, sempre em fileiras. Os vaqueiros saltavam no ritmo da música enquanto se deslocavam e se destacam pelo figurino, lanças ricamente decoradas que empunhavam para o alto.

\section{Toada, Marujada de Guerra e Batucada}

A música pontua todos os instantes das apresentações. São executadas toadas novas e antigas, e, em determinados momentos, como durante a fala do Apresentador ou do Amo do Boi, toma conta uma atmosfera musical, essencialmente instrumental. Não houve intervalos de silêncio durante os espetáculos.

A música exerce um papel fundamental no Boi Bumbá de Parintins. Como expresso no Roteiro de Apresentação do Garantido deste ano, é o "fio condutor lítero-musical". Ainda segundo este Roteiro, as toadas dão suporte aos espetáculos, contextualizam os segmentos artísticos da apresentação e proporcionam ritmo e dinâmica para cada quadro artístico ou item individual.

As toadas, compostas especialmente para cada edição do Festival, apresentam as personagens que surgem na arena, como uma homenagem ao Pajé, à Cunhã Poranga, mas também falam sobre as lendas, rituais e figuras típicas apresentadas nas cenas.
Algumas deste ano continham sons de respiração, grunhidos de feras, falas de personagens que participavam da história contada na música. Elas dão uma conotação de "musical folclórico" ao espetáculo, tal qual propõe o Roteiro de Apresentação da Arena do Caprichoso, de 2016.

Nesse sentido, as toadas desempenham um papel fundamental na dramaturgia dos espetáculos, como um dos principais elementos narrativos. Em outros momentos, elas exaltam o Garantido ou o Caprichoso, a Amazônia, a emoção provocada pelo Boi ou o espírito guerreiro que lhe é característico. Outras são feitas especificamente para a Galera, para promover sua participação entusiasmada.

Batucada é o nome dado ao "corpo de sustentação rítmica das toadas" do Garantido, como coloca seu Roteiro de Apresentação (2016). A Marujada de Guerra é o grupo correspondente do Caprichoso. Cada um conta com um número aproximado de 400 ritmistas, que se distribuem na arena em 2 grupos, posicionados lado a lado, cada um com um regente. Os principais instrumentos utilizados são: surdos, repiques, caixinhas, chek-cheks e palminhas.

Tanto a Marujada quanto a Batucada executavam movimentos de forma sincronizada, em determinados momentos: iam todos para frente e para trás, mudavam a direção espacial, girando o corpo nas quatro direções (de frente para a arena, voltado para a direita, de costas, voltado para a esquerda, até retornar à relação frontal em relação à arena), saltavam. Os integrantes da Marujada de Guerra e da Batucada se vestiam de modo uniforme, e 
${ }^{4}$ Modo como torcedores de um Boi se referem ao outro Boi. os figurinos eram diferentes para cada dia de espetáculo. Do conjunto de toadas criadas para cada Boi para o Festival, em torno de 20, elegia-se uma por noite para competir enquanto item a ser pontuado pelos jurados, como a "Toada, Letra e Música”.

\section{Alegoria}

As alegorias ${ }^{3}$ são "esculturas gigantes" que ganham animação e compõem a "ambientação cenográfica" dos espetáculos, dando "suporte ao desenvolvimento do contexto de cada quadro", para usar os termos dos próprios Bois, expressos em seus Roteiros, deste ano.

Algumas entravam em módulos separados, empurrados por um grupo numeroso de pessoas e, aos poucos, distribuíam-se pelo espaço, encaixando-se para formar uma imagem. Outras funcionavam como peças independentes, cada qual uma imagem completa, que compunha no espaço com outras alegorias, formando um grande cenário. Costumavam ser dispostas na parte central da arena do Bumbódromo. Algumas delas atingiam mais de 20m de altura.

As alegorias funcionavam como cenários para as diferentes cenas. Elas ocupavam a vastidão da arena do Bumbódromo, com suas proporções agigantadas, e delimitavam esse espaço, criando vazios onde os grupos de dançarinos ocupavam. Aos poucos, elas eram introduzidas por grupo de pessoas uniformizadas, que as empurravam e posicionavam no espaço, para serem retiradas ao final de determinada cena, geralmente com luzes baixas para chamar pouca atenção para essa retirada ou com o foco em algum item e o restante em penumbra.

Enquanto as alegorias eram posicionadas, a cena se desenrolava, com um número grande de brincantes executando coreografias em grupos. As estruturas alegóricas dialogavam com o tema escolhido pelo respectivo Boi para aquela edição do Festival e com o mote de determinada cena. Desse modo, são fundamentais na dramaturgia, pois ajudam a "contar a história" que está sendo narrada nas toadas. Cada quadro artístico era composto por um conjunto alegórico.

Foi recorrente o surgimento de uma personagem a partir de uma alegoria, o que criava um efeito de surpresa, visto que ela não havia sido identificada anteriormente. O Pajé, a Rainha do Folclore e a Cunhã Poranga, para citar alguns, desceram de distintas alegorias sobre uma estrutura móvel. Em outros momentos, alguns grupos de brincantes dançaram ou atuaram nos espaços das alegorias, ocupando-as de distintas formas.

Outro recurso das alegorias eram os movimentos que elas executavam, como a articulação de mãos, dedos e cabeças, chamados de robótica - movimentos que se combinavam e se repetiam, ora indo de um lado para o outro, para cima e para baixo. Geralmente, esses movimentos tinham início depois que as alegorias estavam devidamente posicionadas e contribuíam para dar dinamismo à cena. Algumas delas recebiam uma pintura com tintas 


\section{Saulo Nepomuceno}

Juliana Veloso Sá

\section{Matheus Lavinscky}

que se ressaltavam quando em contato com a luz negra e, assim, criavam um efeito de grande intensidade.

Antes de entrar no Bumbódromo, as alegorias já se encontravam em um pátio externo, do qual saíam empurradas para o centro da arena. Por sua exposição ao sol e possíveis chuvas, no pátio ou no centro da arena, o material utilizado em sua fabricação deveria ser bastante resistente.

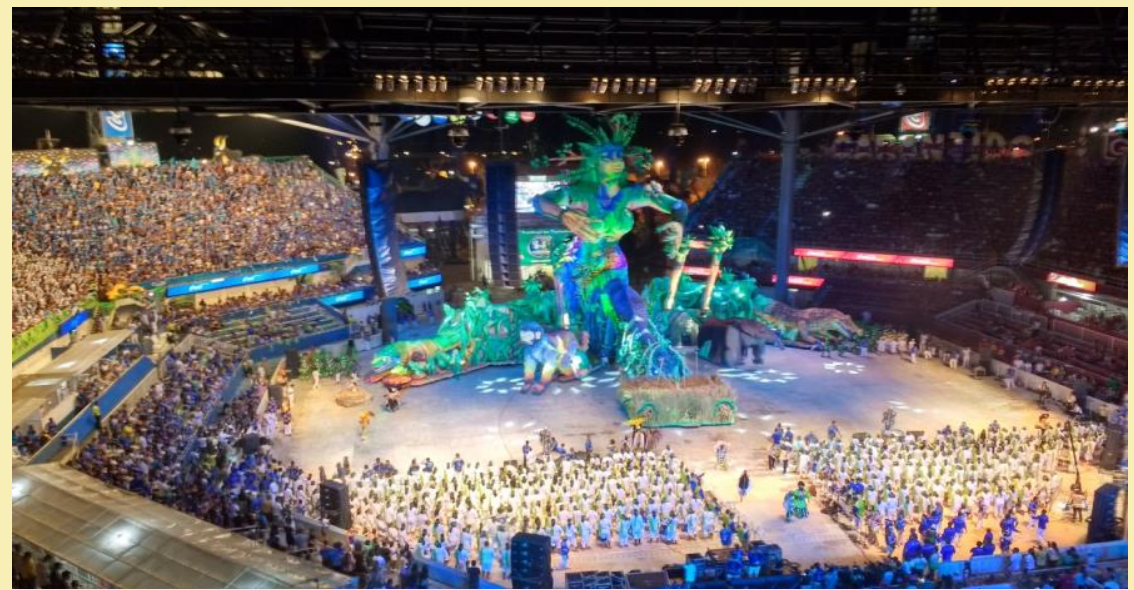

Foto 06: Alegoria do Caprichoso no Bumbódromo (Edson Farias)

\section{Iluminação}

A luz é um diferencial dos Bumbás de Parintins no universo das manifestações da cultura popular brasileira. O Bumbódromo oferece uma boa estrutura para iluminação. Predominam, em cada apresentação, a cor correspondente do Bumbá - vermelho para o Garantido e azul para o Caprichoso. É interditado aos dois usar na arena as cores correspondentes ao Boi contrário ${ }^{4}$. Em alguns momentos, utilizam-se de tons próximos, como o lilás pelo Garantido e o amarelo ou laranja, pelo Caprichoso, com o devido cuidado para que essas cores, quando em contato com outras matizes nos figurinos e alegorias, não reflitam a cor do contrário.

Algumas formas de usar a luz foram recorrentes: cobrir toda a arena com uma cor de luz, sendo as mais frequentes o azul, vermelho, amarelo e branco; projetar desenhos com a luz no chão da arena, os mais comuns eram em formato de estrelas, ora branco, ora coloridos. Em outros momentos, um canhão de luz jogava um foco sobre determinada figura, como a Sinhazinha, a Cunhã Poranga ou o Boi, enquanto o restante do espaço permanecia em penumbra. Esse recurso permitia ressaltar determinado item e fazê-lo "crescer" aos olhos dos espectadores, visto que todo o resto do espaço perdia seus contornos enquanto aquele ganhava mais nitidez e destaque. Outro efeito de luz usado era o de estroboscópio, que, ao apagar e acender, gerava dinamismo na cena.

A luz se mostrou em sintonia com outros elementos, como o figurino e a alegoria. Alguns figurinos ficavam bastante ressaltados em função da interação com a luz, como as plumas em diversos tons. Foram também usados recursos de luz negra que, quando incidia sobre figurinos e alegorias, provocava efeito de grande intensidade visual.

\section{Galera}




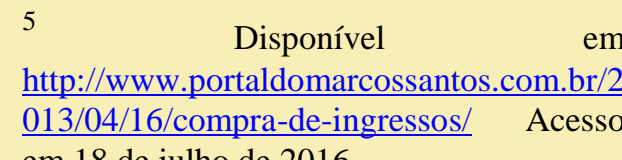
em 18 de julho de 2016.
A Galera faz parte do conjunto de itens julgados no Festival. É uma torcida organizada que contribui, em muito, para a atmosfera empolgante e envolvente do Boi de Parintins. É um público que conhece as músicas, que está pronto para responder aos estímulos propostos pelo Boi, para seguir coreografias - um público qualificado, que "vai dar força a cada momento dos espetáculos do boi" (Roteiro do Garantido, 2016).

Durante toda a apresentação, a Galera que torce para o respectivo Boi participa, canta, grita, faz coreografias e fica em evidência, sob os holofotes do Bumbódromo, um "grande coro que embala as apresentações", nos termos do Roteiro do Caprichoso. Enquanto isso, a torcida do outro Boi permanece em silêncio e no escuro. A situação se inverte quando o outro Boi toma a arena.

Cada torcida, com mais de 10 mil pessoas, canta e realiza movimentos sincronizados usando, especialmente, os braços e objetos distribuídos pelos Bois. Guiadas por um pequeno grupo situado na parte de baixo da arquibancada, respondiam aos estímulos e coreografias ensinados por eles, com bastante empolgação, em sintonia com a música. Todos levantavam as mãos no ritmo da música, agitavam no ar lenços coloridos, que ora formavam uma figura, como a bandeira do Brasil, acendiam objetos luminosos, entre outras coisas. Mas, além de executar movimentos, deviam fazê-lo com muito entusiasmo e responder aos chamados do Apresentador com gritos de empolgação.

Foi possível observar que muitas pessoas que estavam na Galera do Boi que se apresentou primeiro foram embora no intervalo entre os dois espetáculos e que, durante este intervalo, chegavam outros para assistir, que entravam no Bumbódromo naquele momento ou que haviam dançado ou tocado há pouco e ainda portavam os figurinos.

A entrada no Bumbódromo para as pessoas que compõem a Galera é gratuita. Desde as $12 \mathrm{~h}$, as arquibancadas começam a ser ocupadas pelas torcidas vermelho e branco, de um lado, e azul e branco, do outro. A cor da roupa dos torcedores é um elemento importante. Não é permitida a entrada de pessoas portando tons do Boi contrário ou outros que se destaquem na mancha de pessoas na arquibancada, que devem ser, majoritariamente, vermelha e azul.

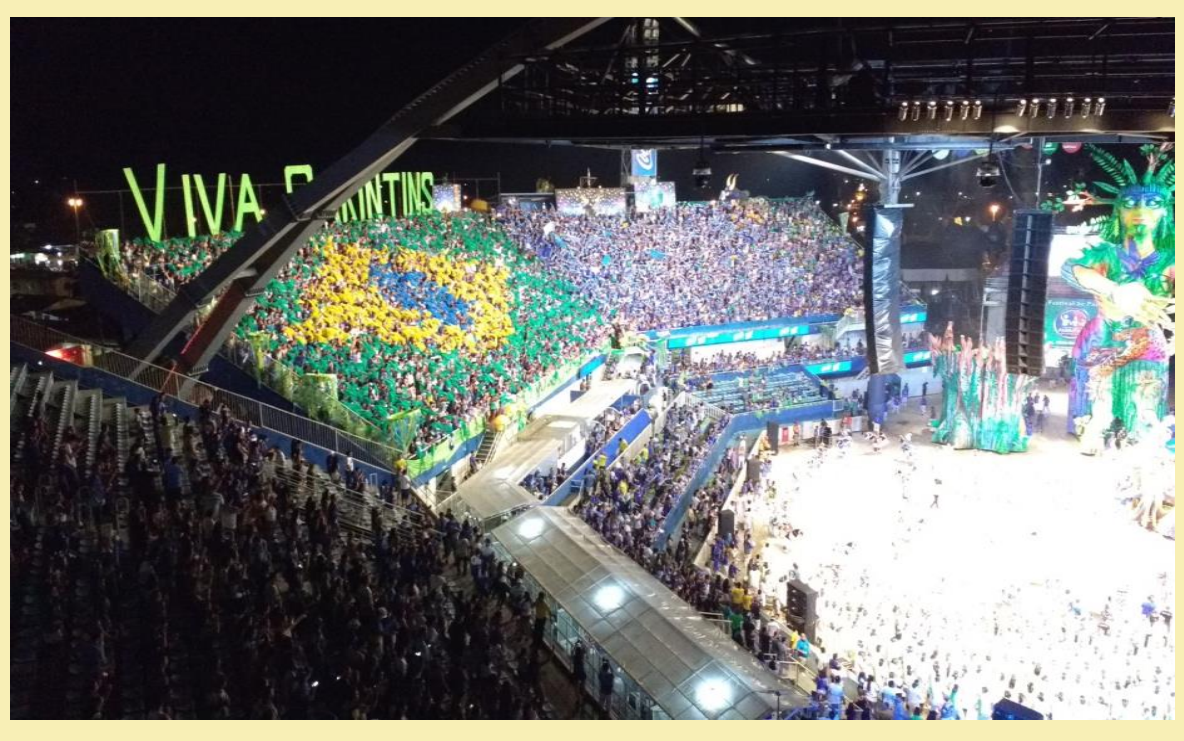

Foto 07: Galera do Caprichoso no Bumbódromo (Edson Farias) 
O Festival Folclórico de Parintins já foi realizado em muitos locais diferentes. Atualmente, acontece no Bumbódromo, um espaço construído especificamente para isso, que se localiza em uma área central da cidade e comporta um público de pouco mais de 16 mil pessoas.

Apesar de ser uma arena, o uso que se faz do espaço é quase exclusivamente frontal, como um palco italiano; não é, portanto, um uso que aproveita as diversas direções em torno do espaço cênico, possibilidade que a arena oferece, visto que o público se distribui em torno de todo esse espaço. Com isso, privilegia-se a visão daqueles que estão sentados nas arquibancadas centrais e especiais dos dois Bois, dos jurados e dos que estão nos camarotes - vide a planta do espaço, abaixo.

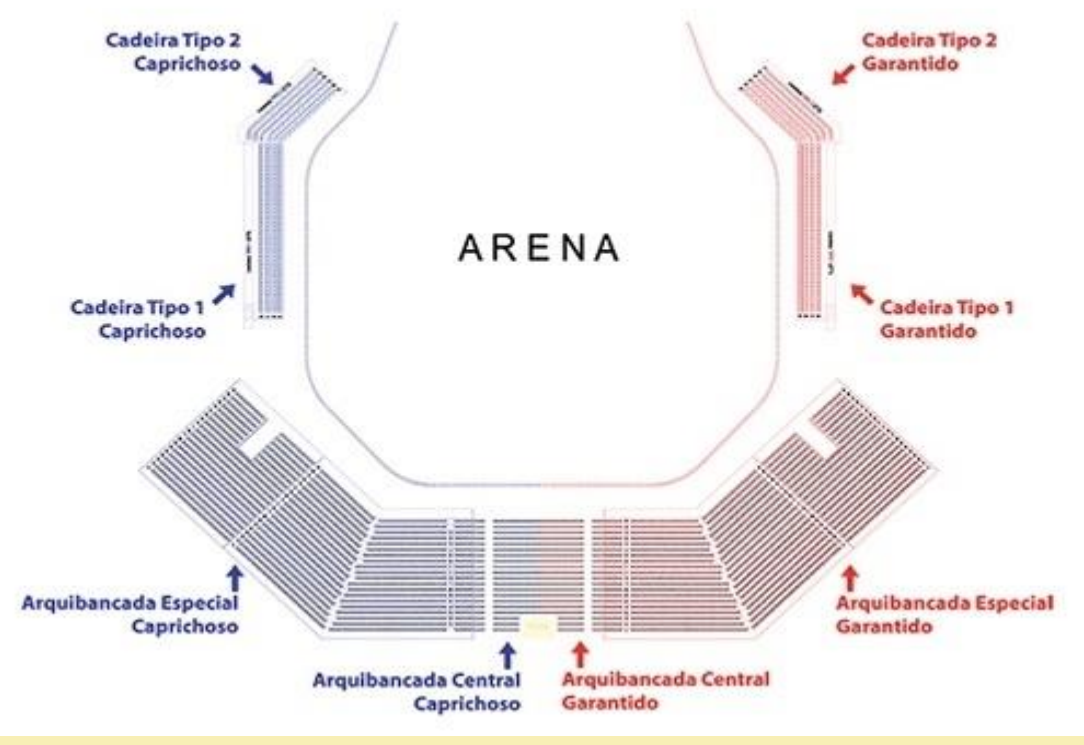

Figura 01. Planta do Bumbódromo
Em entrevista, Chico Cardoso, integrante da Comissão de Arte do Caprichoso, comenta que um desenvolvimento futuro do Boi Bumbá de Parintins seria começar a utilizar o espaço cênico do Bumbódromo como uma arena.

Além de frontal, o espaço era normalmente usado de forma simétrica, equilibrada. As alegorias costumavam ocupar o fundo (parte mais próxima do local por onde entram) e o centro da arena. Por entre elas, ao lado e em frente, distribuíam-se os grupos de dançarinos. Cada grupo ocupava um lugar no espaço e se distribuía em filas ou círculos, em geral, segundo alguma forma geométrica, não de modo aleatório. Se, de um lado, um determinado número de pessoas desenhava um círculo, do outro, costumava haver uma forma equivalente. Nem sempre os desenhos eram totalmente idênticos, mas costumavam ser semelhantes e manter um equilíbrio entre a forma de distribuição de brincantes e alegorias nas lateralidades da arena.

Por diversas vezes, a cena permaneceu com uma mesma imagem por determinado tempo. As alegorias já se encontravam devidamente posicionadas, cada grupo de dançarinos bailava em seu lugar, e a forma de ocupar o espaço da arena permanecia inalterada por longos minutos. $\mathrm{O}$ que conferia movimento e intensidade à cena era, principalmente, a música e o movimento da Galera. A música se desenvolvia com seus ritmos e movimentação própria, enquanto a Galera cantava e fazia suas coreografias, sem deixar que a cena, que pulsava em movimentos sem se alterar significativamente, caísse 
em desinteresse para aqueles que assistiam. Essa situação se repetiu algumas vezes em ambos os Bois.

A maioria dos grupos de dançarinos realizava um conjunto de movimentos que se repetia, por um período de tempo, sem mudarem a posição que ocupavam no espaço, fosse em filas horizontais ou verticais, em círculos etc. Deslocavam-se para um lado e outro, para frente e para trás, mas não desfaziam o desenho que compunham no espaço. Ocupavam o espaço da arena e o modelavam com as formas e cores dos figurinos, que se distribuíam de modos diferentes por cada grupo pelo espaço.

O item Organização do Conjunto Folclórico está voltado para a organização da execução do espetáculo, a harmonia entre a movimentação cenográfica e coreográfica (itens individuais e coletivos), bem como para a distribuição espacial dos elementos na arena. "Todos os elementos devem estar dispostos de forma coerente e adequados numa dinâmica que preserve o respeito pelo espaço cênico, para que seja possível o mais perfeito entendimento visual de cada momento" (Roteiro do Garantido, 2016).

Mas a festa dos Bumbás de Parintins não acontece somente no Bumbódromo. Além dos currais, locais de ensaio dos Bois, ela toma as ruas, especialmente aquela em frente à Igreja e outra às margens do Amazonas. As casas manifestam a filiação dos moradores pela decoração em tons azuis ou vermelhos.

E a rede de pessoas envolvidas na festa dos Bumbás também ultrapassa os limites da Ilha Tupinambarana. Além de se dirigirem para Parintins torcedores e apreciadores de diversas cidades do
Amazonas e de fora do Estado, há brincantes e dançarinos que são de cidades "próximas", como Manaus e Presidente Figueiredo, no Amazonas, e Juriti e Santarém, no Pará. Elementos que se mostraram importantes para a divulgação e mobilização de uma rede de pessoas que se dirigem para o Festival foram a mídia e as redes sociais.

\section{Celebração}

Alguns elementos se ressaltaram na apresentação dos BoisBumbás e na festa de rua em Parintins por seu caráter celebrativo. O Festival marca uma vivência coletiva do povo de Parintins. As apresentações mobilizam um número muito grande de pessoas nas mais diversas tarefas e tipos de envolvimento. Outros tantos se dirigem ao Bumbódromo nos dias de Festival para comporem a Galera, que, por seu grande envolvimento afetivo e festivo, intensificam o caráter celebrativo dos Bumbás parintinenses. "É a Galera que mantém acesa a chama da alegria durante as 2 horas e meia de cada apresentação do boi" (Roteiro do Garantido, 2016).

$\mathrm{Na}$ arena, a figura da santa padroeira da cidade, Nossa Senhora do Carmo, confere um tom religioso a essa celebração, apesar do caráter celebrativo não se reduzir ao elemento de religiosidade.

$\mathrm{Na}$ rua, um contingente grande de pessoas festejam, dançam e bebem ao som de toadas ou outras músicas. Muitas portam as cores azul e vermelho em suas vestes e grande parte, sobretudo as 
mulheres, usa adereços com penas (colares, cocares, brincos) nas cores dos Bois, em uma exaltação de elementos indígenas.

$\mathrm{O}$ forte envolvimento afetivo dos torcedores, manifesto em muitas entrevistas, conversas informais e na persistência para enfrentar filas, chuva e sol e entrar na Galera de cada Boi, dá o tom dessa vivência coletiva. Para muitos, uma "paixão" que foi transmitida pela família.

\section{c) Tradições, espetáculo e emoção}

Por Saulo Nepomuceno

No próprio barco que faria o trajeto entre a capital do estado do Amazonas e a ilha de Tupinabarana, onde se situa a cidade de Parintins, tivemos a oportunidade de conhecer pessoas que embora se declarassem torcedoras apaixonadas de algum dos bois, participariam do festival in loco pela primeira vez. Do mesmo modo, foi possível conhecer brincantes que nunca perdiam a oportunidade de estar em Parintins durante a festa. Família inteiras e por vezes grandes grupos de amigos que antecipariam durante a viagem parte do cenário que seria encontrado na cidade, sobretudo no que diz respeito à forte presença das cores vermelha, símbolo do Boi Garantido, e azul, respectiva ao Boi Caprichoso, e das toadas, expressões musicais de forte apelo rítmico e dançante que marcam tanto a experiência no interior do Bumbódromo quanto a vivência das ruas da cidade no curso da festa.
Nas falas de alguns participantes, principalmente aqueles que fazem questão de assistir ao festival ao vivo todos os anos, ganha destaque a capacidade da festa em "capturar" novos participantes ao construir um forte desejo de retorno - retorno que seria em grande parte garantido pela capacidade do festival em proporcionar intenso divertimento e deslumbramento.

Desse modo, diferentes tipos de vinculação são apresentados. Ganham destaque nas narrativas diversos aspectos relacionados às tradições e aos amplos significados culturais que o evento mobiliza. $\mathrm{O}$ destaque conferido a esses aspectos não parece rivalizar com o incremento de novos elementos simbólico-materiais ao corpo da festa, sobretudo no que concerne às facetas espetaculares da festividade. Ao contrário, a gama de significações culturais tradicionalizadas no longo percurso das manifestações ligadas à brincadeira de boi na região alimentam tanto as intensas dinâmicas e inquietações técnicas e artísticas daqueles envolvidos na produção do espetáculo, quanto animam e reforçam os vínculos entre os Bois e os brincantes.

Em termos distintos, os aspectos tradicionais tradicionalizados não inviabilizam ou se chocam com as dimensões do espetáculo-entretenimento, tampouco inviabilizam incrementos de novas práticas e símbolos nessas dimensões. Talvez seja fundamental destacar a própria construção das tradições da espetacularidade nos eventos que dão corpo ao festival.

As imagens da exuberância, grandiosidade e até mesmo arrojo criativo e tecnológico são frequentemente mobilizadas de 
maneira articulada à expressão de fortes paixões e emoções ligadas ao patrimônio simbólico tradicional dos grupos. Os bois apresentam a capacidade de reconfigurar ou reafirmar determinadas tradições de maneira indissociável da produção de encantamento espetacularizado.

As falas dos participantes que puderam acompanhar as primeiras formas com que a disputa entre os bois Garantido e Caprichoso se constituiu revelam dinâmicas fundamentais para a compreensão deste entrelaçamento entre a mobilização de símbolos tradicionais e linguagens espetaculares.

A dimensão da violência aparece de maneira recorrente nos relatos dos participantes mais antigos. Conforme as narrativas, os brincantes de cada boi se enfrentavam em violentos duelos, em muitos casos letais. Nenhuma imagem poderia ser mais contrastante com o caráter pacífico com que as torcidas do boi se "enfrentam" atualmente nas ruas e no Bumbódromo. Os embates são hoje majoritariamente marcados por respeitosa jocosidade.

As disputas ganharam diferentes contornos, e as dimensões da beleza, grandiosidade, e a capacidade dos Bois em provocar fortes sensações e emoções dentro e fora da arena passam a compor aspectos fundamentais da disputa.

Os festejos e duelos entre os Bois, que aconteciam nas ruas em seus primeiros momentos, passam a ocorrer em diferentes locais a partir da década de 1960. A rivalidade estética entre os grupos sofre uma escalada fulminante nas décadas seguintes. No fim dos anos 1970 os bois passam a se apresentar num estádio de futebol e posteriormente num palco de madeira montado no local onde seria construído o Bumbódromo em 1988.

Após um conjunto de reformas, a arena onde os Bumbás disputam o título comporta hoje cerca de 30 mil pessoas. Em uma das laterais se posiciona a Galera do Boi Garantido, na outra a Galera do Boi Caprichoso. Diante da imensa quantidade de torcedores apaixonados, grandes filas se formam nos dias anteriores ao festival, e muitas horas de espera são necessárias para garantir um lugar em cada um dos três dias de apresentação.

$\mathrm{O}$ esforço dos participantes das Galeras é hercúleo. Se pensarmos que a maior parte das pessoas passou muitas horas ou mesmo dias nas filas e que cada Boi possui duas horas e trinta minutos para se apresentar em cada dia do festival, temos alguma dimensão da paixão envolvida na brincadeira e das emoções mobilizadas no desempenho das Galeras na arena. Somam-se às incontáveis horas de fila uma nova maratona de vigorosas coreografias, que não podem ser negligenciadas em momento algum pelos participantes das Galeras, visto que esse desempenho coletivo, também marcado pelo imperativo da espetacularidade, está sendo rigorosamente avaliado.

Com vários meses de antecedência os Bois lançam o conjunto de toadas respectivas aos itens apresentados na arena Desse modo, a maior parte dos participantes das Galera tem a chance de memorizá-las e consequentemente contribuir para a performance do Boi de sua torcida. Muitos participantes deixam o Bumbódromo assim que o "Boi contrário" inicia sua apresentação. 
Durante a apresentação do Boi rival, a Galera oposta deve manter silêncio. Manifestações de apoio ou repúdio durante a outra apresentação podem acarretar em perdas na pontuação, regra que contribui para o clima de respeito e civilidade marcantes nas relações entre os torcedores opostos não apenas no interior da arena, mas em toda a cidade.

As Galeras possuem papel determinante na dinâmica do espetáculo, pois interagem com todos os itens apresentados. Embora os itens constituam atualmente um conjunto fechado, variaram bastante ao longo das décadas. Não há uma ordem pré-estabelecida em que os Bois devam apresentar os itens. Embora obrigatórias, as distintas alegorias, coreografias e personagens podem ser apresentadas na ordem em que as equipes de produção dos bois decidirem. Essa estratégia contribui para a fluidez do espetáculo, indicando a possibilidade do desencadeamento de surpresas, recebidas, em geral, com euforia por parte das Galeras e do público das arquibancadas pagas e camarotes.

São muito comuns as conversas, discussões e especulações em torno de supostas "personalidades" éticas e estéticas de cada Boi. Alguns torcedores do Boi Garantido costumam dizer que o seu Boi manifesta maior respeito às tradições da brincadeira. Seja no que indica a observação de aspectos religiosos relacionados ao festival, sobretudo no que tange ao calendário, quanto em termos da conservação da integridade simbólica de certos itens em disputa, tais como a estrutura musical das toadas e outros elementos constitutivos da dinâmica cênica, coreográfica e ritualística do festival. O Boi Garantido aparece nas falas de alguns de seus torcedores enquanto mais próximo e representativo dos segmentos populares, além de seus fãs afirmarem que sua Galera é mais efusiva e vibrante.

Outra provocação comum é o questionamento da univocidade da narrativa de origem do Boi Caprichoso. Enquanto o Garantido possui versões mais centralizadas no legado da família Monteverde, o Caprichoso é acusado de imprecisão nesse aspecto, dadas algumas disputas internas em torno de sua origem.

No compasso em que se mobilizam, em relação ao Boi Garantido, ideias em torno da emoção, do caráter vibrante e fanático de sua torcida e de seu apelo popular também são construídas imagens em torno da "personalidade" do Boi Caprichoso.

Alguns torcedores do Boi Caprichoso gostam de destacar a atenção aos detalhes, o esmero técnico na execução das toadas, fantasias, alegorias, coreografias além de uma maior disposição para inovação e incorporação de novas narrativas e de elementos tecnológicos. Torcedores mais tradicionalistas do Boi Garantido chegam a acusar o Boi Caprichoso de descaracterizar aspectos centrais da forma "toada", ao incorporar de maneira "populista" elementos musicais sabidamente capazes de produzir impacto no espetáculo na arena. O Boi Caprichoso também costuma ser apontado como portador de uma torcida supostamente mais elitizada. Em determinadas falas, alguns participantes destacam os usos político-eleitorais que são feitos dessas imagens, embora esses 
temas tenham sido frequentemente evitados pela maior parte desses brincantes.

A estrutura aberta do espetáculo, no sentido de não haver um script ou ordem estabelecida de apresentação dos elementos, abre margem para combinações infinitas dos 21 itens e também para a articulação de soluções rápidas e inesperadas, inclusive durante as apresentações.

Em diferentes ocasiões, os profissionais envolvidos diretamente na montagem e execução do espetáculo destacam a necessidade do improviso. De ponto de vista leigo de boa parte da audiência, em relação a determinadas tecnicalidades, essas soluções e improvisos dificilmente são percebidas. Todavia, em diversas ocasiões, o recurso a essas práticas também guarda relações com toda uma série de contingências pelas quais as imensas equipes de artistas e especialistas passam ao longo de todo o processo de montagem da festa, sobretudo em relação às inseguranças relativas ao financiamento do festival.

Interesses políticos pouco transparentes, negligências e alguns atos discricionários por parte dos poderes municipais e estaduais contribuem, nas falas de determinados profissionais e brincantes, para que os Bois se vejam obrigados a configurar e reconfigurar suas apresentações conforme a disponibilidade de recursos.

O orgulho em relação à espetacularidade dos eventos, e um certo saudosismo em torno de anos mais opulentos do ponto de vista financeiro, por vezes se expressavam numa espécie pedido de "desculpas" ao visitante, nas falas recorrentes de profissionais e brincantes em relação à "crise”. O espetáculo de 2016 foi considerado por muitos desses produtores e espectadores aquém de suas altíssimas expectativas.

$\mathrm{Na}$ fala de algumas pessoas, as dificuldades com as verbas também foram responsáveis pela potencialização da vocação criativa do povo parintinense. Segundo essas narrativas, várias soluções tecno-estéticas foram encontradas para uma série de problemas, e a festa no Bumbódromo pôde produzir a euforia e o encantamento costumeiros.

A configuração do espetáculo mescla elementos e personagens recorrentes nas diferentes manifestações culturais ligadas ao bumba-meu-boi pelo país, no entanto o boi-bumbá de Parintins carrega profunda particularidade na exata medida em que realiza incorporação espetacularizada de múltiplos elementos referenciados às diversas culturas indígenas e caboclas da região Norte.

Se examinarmos alguns dos vinte e um itens que compõem a apresentação ao longo dos três dias, podemos observar o peso conferido às matrizes culturais da região. Se de um lado observamos a presença das figuras clássicas do auto do boi, como Pai Francisco e Mãe Catirina, o Amo do boi e a Sinhazinha da fazenda e referências a outros símbolos importantes das culturas nordestinas, como o item da Vaqueirada, do outro vemos múltiplas figuras ligadas ao cotidiano e ao imaginário amazônico. 
O item Ritual indígena tem por objetivo a encenação alegórica de algum ritual indígena amazônico; a figura da CunhãPoranga representa a força e beleza da mulher da Amazônia; o padre do bumba-meu-boi dá lugar ao Pajé, sacerdote das tribos; o item Tribos indígenas busca representar artisticamente alguma das múltiplas etnias indígenas da região; os Tuxauas representam os chefes das tribos; o item Figura típica regional visa destacar algumas figuras simbólicas da região, como os caboclos e caboclas, mateiros e seringueiros; assim como o item Lendas Amazônicas confere destaque ao repertório de lendas regionais.

A mobilização desses símbolos potencializa forte identificação por parte das pessoas que vivem em outros estados da região Norte. Além dos participantes vindos de diversas regiões do estado do Amazonas, alguns interlocutores apontam a grande presença de brincantes dos estados do Pará, Rondônia e Acre, seguidos pela presença minoritária de pessoas de outras regiões do país e turistas estrangeiros.

\section{A festa nas ruas}

Embora a presença majoritária de turistas seja oriunda da própria região Norte, pessoas de todo o país e turistas estrangeiros prestigiam todos os anos o festival folclórico de Parintins. Embora a cidade costumeiramente pacata estivesse extremamente agitada antes e durante o festival de 2016, moradores e pequenos comerciantes reclamavam com frequência da menor quantidade de turistas. A crise econômica era mais uma vez acionada nas falas. Apesar do menor volume de turistas, as ruas de Parintins tornam-se um "caldeirão" de diferentes vivências festivas e intercâmbios culturais.

Foto 08: Avenida Amazonas, Parintins (Edson Farias)

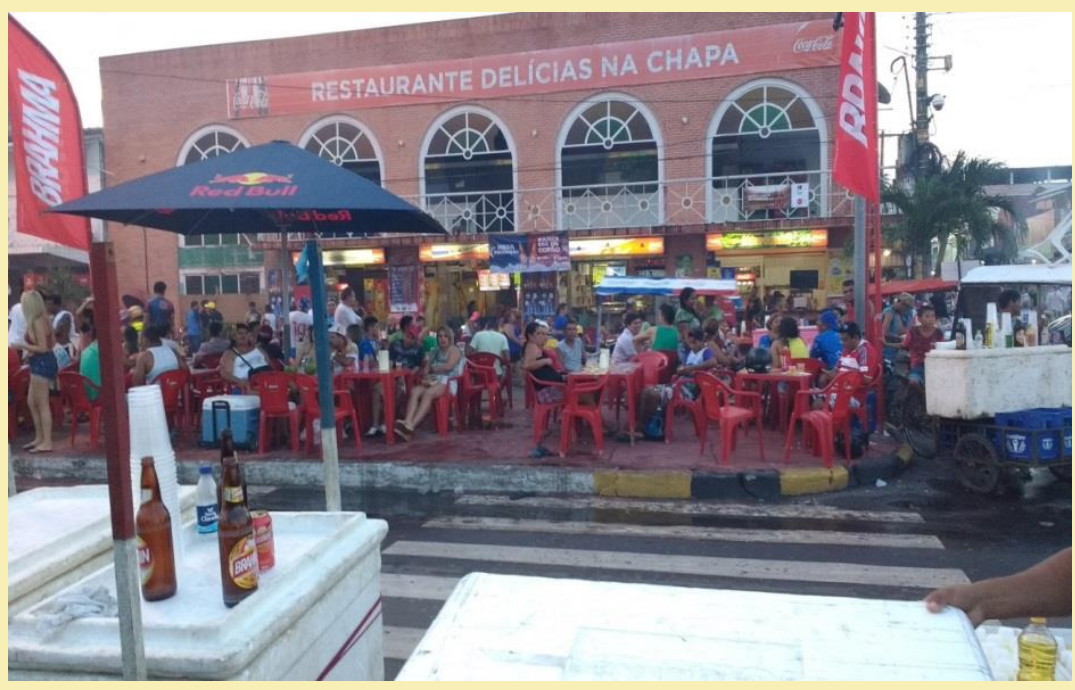

Conviviam com o mar vermelho e azul de casas, carros, motocicletas, ruas, calçadas, roupas, chapéus, belos adereços de penas e com a onipresença das toadas dos bois no último volume, pessoas vestidas das mais diferentes formas, assim como marcavam grande presença estilos musicais diversos, sobretudo aqueles de grande sucesso nacional, articulados a outras formas de expressão.

Diferentes formatos de festividade se afirmam em distintas partes da cidade. A dimensão alcançada pela festa impede que o festival permaneça circunscrito em torno de seus símbolos e práticas 
festivas mais caras. A quantidade e a diversidade de pessoas reunidas dão margem a múltiplas possibilidades de vivências festivas.

Nas áreas próximas ao Bumbódromo, uma grande quantidade de vendedores ambulantes convive com uma série de bares e lanchonetes prontas para saciar os famintos espectadores da arena. Um intenso burburinho de torcedores, muitos que não conseguiram entrar nas Galeras, acompanham pelas tevês e telões a transmissão televisiva das apresentações.

Várias famílias, que transformam suas casas em pequenos estabelecimentos comerciais durante o festival, colocam suas tevês do lado de fora da casa para atrair participantes da festa para a transmissão do evento. A cidade tingida de vermelho e azul se diverte entre incontáveis litros de cerveja e outros incontáveis litros de caldos e sopas regionais enquanto se discute intensamente a dinâmica do espetáculo.

$\mathrm{Na}$ praça da maior igreja católica da cidade, e em suas imediações, podemos encontrar, antes, durante e depois das apresentações na arena, cenários totalmente distintos. Durante o dia, as várias barraquinhas montadas na praça da igreja oferecem roupas, acessórios, souvenires, comidas rápidas, bebidas, produtos com as cores e símbolos dos bois, entre uma infinidade de mercadorias. $\mathrm{O}$ fluxo de pessoas é intenso, e os bares localizados nas proximidades da igreja ficam lotados de pessoas. O espaço não é suficiente para a quantidade de mesas e clientes que tomam conta das ruas próximas.
A orla da cidade também vive grande agitação diurna durante o festival. Uma série de bares e restaurantes recebem muitos clientes brincantes. Os símbolos e cores dos bois aparecem de forma mais marcante nessa localidade de vivência festiva da cidade, assim como as toadas executadas mecanicamente e ao vivo estão presentes de ponta a ponta.

A orla parece se apresentar como um importante ponto de encontro de torcedores de ambos os bois durante o festival. Grupos musicais e um público composto por torcedores vestidos tanto de vermelho quanto de azul dividem o palco, a rua e as mesas pacificamente, alternando toadas do Garantido e Caprichoso.

As formas de vivência festiva na praça e áreas próximas à igreja no período noturno apresentam-se de maneira completamente diferente. Nota-se claramente a presença de um público mais jovem, inclusive muitos menores de idade. As cores dos bois continuam presentes, mas em menor quantidade.

Situados entre os bares e barracas de drinks, os carros preparados com "carretinhas" (um pequeno reboque equipado com uma parede de aparelhamentos de sonorização) e posicionados a pouquíssimos metros uns dos outros disputam a atenção das pessoas. Em determinado momento, cinco carretinhas tocavam simultaneamente músicas de estilos diferentes, como sertanejo funk, arrocha, house music e forró, produzindo uma miscelânea quase indistinguível de sons.

Alguns interlocutores destacam que grandes festas nessa área da cidade já foram promovidas por grandes empresas, 
entretanto, as autoridades eclesiais passaram a vetar a realização desse tipo de evento.

A presença de uma grande quantidade de pessoas na localidade pôde ser observada apenas no primeiro dia do festival. Uma relevante diminuição do público foi observada nos dias seguintes. Nas noites seguintes a quantidade de carretinhas foi drasticamente reduzida e um severo toque de recolher colocado em prática pelas autoridades policias.

A grande presença de adolescentes nessa ambiência festiva, bastante precária em certos sentidos, expressa importantes demandas juvenis por divertimento não atendidas completamente pelas dinâmicas de caráter mais institucionalizado do festival. A grande presença de adolescentes e jovens adultos entre os artistas, nos currais dos bois e no Bumbódromo não significa que todos os jovens se sentem contemplados pelos eventos e estéticas peculiares ao festival e parece não haver esforço algum do poder público e dos organizadores da festa no sentido de atender essa demanda.

O grande fluxo de pessoas dos mais diferentes lugares do país não se repete em outros momentos do ano em Parintins. Tratam-se de oportunidades inestimáveis que carecem de estruturas adequadas para que todas as pessoas, no caso específico as jovens, possam intercambiar infinitos saberes, práticas e símbolos.

As administrações públicas municipais e estaduais aparecem nas falas como pouco interessada nessas questões. Integrantes de ambos os bois destacam que a grandiosa festividade sofre com inúmeros descasos, entre eles, talvez o mais grave - o descaso com a formação de novos artistas.

A cidade inteira manifesta profundo orgulho da profusão de artistas que circulam por suas ruas. Músicos, escultores, estilistas, pintores, desenhistas, dançarinos, poetas, compositores, coreógrafos se veem, muitas vezes, pressionados a abandonar a paixão pelos ofícios e pelos Bois na busca de melhores oportunidades de sobrevivência. As escolinhas de ambos os bois se encontram fechadas. Esses importantes locais de transmissão e renovação dos saberes e fazeres antes fundamentais para a construção do espetáculo, hoje fazem parte da memória daqueles que deles participaram

$\mathrm{O}$ dueto entre a paixão dos torcedores e o cuidado perfeccionista dos profissionais envolvidos na produção do espetáculo só pode produzir um desejo irredutível pela grandiosidade. As histórias dos bois nos mostram que os profundos mergulhos no folclore e na tradição nunca miram o retorno a supostas formas idealizadas do passado - os Bois parecem não estar acostumados a dar passos atrás em suas conquistas. As toadas precisam estar na boca da Galera, as coreografias perfeitamente ensaiadas, as alegorias e fantasias impecáveis, pois a festa do ano seguinte precisa ser maior, mais bonita, mais emocionante e, de preferência, vitoriosa. 